\title{
TUBERCULOSIS IN NSW, 1991 TO 1999
}

\section{Communicable Diseases \\ Surveillance and Control Unit \\ NSW Department of Health}

Tuberculosis continues to be a major cause of mortality worldwide. While NSW and the rest of Australia have among the lowest rates of disease in the world, tuberculosis continues to pose a public health threat, especially with the dual emergence of multi-drug-resistant strains, and the HIV epidemic in our region. In this report we review the epidemiology of reported tuberculosis cases in NSW from 1991 to 1999 . A review of multi-drugresistant tuberculosis will be presented in a forthcoming article in the NSW Public Health Bulletin.

Tuberculosis is caused by infection with the bacterium Mycobacterium tuberculosis, or more rarely in Australia, $M$. bovis and $M$. africanum. Only about 10 per cent of persons infected with these bacteria, however, will ever develop tuberculosis. In the majority of infected persons, the infection lies dormant, neither causing disease nor capable of transmission. Once tuberculosis develops, symptoms vary according to the body part affected, but usually include fatigue, weight loss, fever, night sweats, and cough. Diagnosis depends on clinical suspicion, and is supported by finding acid-fast bacilli in sputum smears,

\section{TABLE 5}

PATIENTS NOTIFIED, HOSPITALISED, AND DIED WITH TUBERCULOSIS, NSW, 1991-1999

\begin{tabular}{|lccr|}
\hline $\begin{array}{l}\text { Case } \\
\text { characteristics }\end{array}$ & $\begin{array}{c}\text { Notified } \\
\text { cases }\end{array}$ & $\begin{array}{c}\text { Hospital } \\
\text { admissions } \\
\text { (\%) }\end{array}$ & $\begin{array}{r}\text { Notified deaths } \\
\text { (\% of cases) }\end{array}$ \\
Year of onset & 432 & $63(15)$ & $9(2)$ \\
$1991^{*}$ & 395 & $143(36)$ & $20(5)$ \\
$199{ }^{*}$ & 390 & $216(55)$ & $28(7)$ \\
1993 & 393 & $204(52)$ & $24(6)$ \\
1994 & 443 & $226(51)$ & $22(5)$ \\
1995 & 411 & $191(46)$ & $16(4)$ \\
1996 & 422 & $226(54)$ & $16(4)$ \\
1997 & 385 & $204(53)$ & $27(7)$ \\
1998 & 483 & $207(43)$ & $22(5)$ \\
1999 & 3754 & $1680(45)$ & $184(5)$ \\
\hline Total & & & \\
&
\end{tabular}

culturing the bacteria from clinical specimens and changes in the chest x-ray. Specific treatment involves a suite of antibiotics for at least six months. ${ }^{1}$

Pulmonary tuberculosis can be infectious to others, and persons at increased risk for disease include close contacts of a case, especially those who are very young or old, with underlying conditions such as immune suppression, silicosis, gastrectomy, or with a history of substance misuse. ${ }^{1}$ Cases of tuberculosis are notifiable to public health units (PHUs), and chest clinic staff investigate risk factors, provide education, screening and preventive therapy to close contacts.

\section{METHODS}

Under the NSW Public Health Act 1991, all doctors, laboratories and hospitals must notify suspected cases of tuberculosis to the local PHU. Public health unit staff record case details on a confidential statewide Notifiable Diseases Database (NDD). We analysed the characteristics of cases of tuberculosis, hospitalisations and deaths notified to PHUs between 1991 and 1999. Incidence rates were calculated using the estimated 1997 mid-year population. Country of birth was only reliably available in the database for cases from 1993, and therefore analysis on this variable was only included for cases notified from 1993 to 1999.

\section{RESULTS}

\section{Case notifications}

For 1991 to $1999,3,754$ cases of tuberculosis were notified in NSW, an average of 417 per year. Fewest reports were received in 1998 (385), and most in 1999 (483) (Table 5). The average annual incidence for the period was 6.6 per 100,000 persons. The case rate in 1999 was 7.7 per 100,000 NSW residents.

\section{Demographics}

This average annual incidence varied widely with age: it was highest among persons aged 65 years and older, and lowest among young adolescents. For 1993 to 1999, the average annual incidence was highest among persons born in regions with a high prevalence of tuberculosis (especially Asia), and lowest among persons born in Australia. In 1999, 75 cases (16 per cent) were reported to be born in Australia (1.6/100,000), 282 (58 per cent) in Asia (64.1/100,000), 79 (16 per cent) in Europe (10.8./ 100,000), 9 (two per cent) in Africa $(20.1 / 100,000), 12$ 


\section{TABLE 6}

\section{CHARACTERISTICS OF PATIENTS NOTIFIED WITH} TUBERCULOSIS, NSW, 1991-1999

\begin{tabular}{|llcr|}
\hline Case characteristics & $\begin{array}{c}\text { Cases } \\
\text { (\% total) }\end{array}$ & $\begin{array}{c}\text { Average } \\
\text { annual rate } \\
\text { per 100,000 }\end{array}$ & $\begin{array}{r}\text { Deaths } \\
\text { (\% of cases) }\end{array}$ \\
\hline Residence & & & \\
Sydney area & $3135(84)$ & 9.4 & $134(4)$ \\
Other NSW & $576(15)$ & 2.5 & $47(8)$ \\
Overseas/unknown & $43(1)$ & & $3(7)$ \\
\hline Sex & & & \\
Male & $1983(53)$ & 7.1 & $129(7)$ \\
Female & $1752(47)$ & 6.2 & $55(3)$ \\
\hline Age group & & & \\
& & & \\
$<5$ & $130(3)$ & 3.3 & $3(2)$ \\
$5-9$ & $55(1)$ & 1.4 & $1(2)$ \\
$10-14$ & $46(1)$ & 1.2 & $1(2)$ \\
$15-19$ & $115(3)$ & 3.0 & $0(0)$ \\
$20-24$ & $293(8)$ & 7.2 & $0(0)$ \\
$25-44$ & $1423(38)$ & 8.2 & $22(2)$ \\
$45-64$ & $760(20)$ & 6.3 & $23(3)$ \\
$65+$ & $932(25)$ & 13.0 & $134(14)$ \\
\hline
\end{tabular}

\section{Region of birth (1993-99)}

\begin{tabular}{|c|c|c|c|}
\hline Australia & $548(19)$ & 1.6 & $52(9)$ \\
\hline Europe & $342(12)$ & 6.7 & $32(9)$ \\
\hline Asia & $1656(57)$ & 53.8 & $48(3)$ \\
\hline Middle East & $47(2)$ & 6.0 & $1(2)$ \\
\hline Africa & $69(2)$ & 22.0 & $4(6)$ \\
\hline Oceania & $108(4)$ & 10.6 & $2(2)$ \\
\hline Americas & $32(1)$ & 6.3 & $0(0)$ \\
\hline Not reported & $125(4)$ & & $16(13)$ \\
\hline (Total 1993-99) & 2927 & & $115(5)$ \\
\hline \multicolumn{4}{|l|}{ Main site } \\
\hline Lung & $1853(49)$ & 3.3 & $109(6)$ \\
\hline Lymphatics & $470(13)$ & 0.8 & $6(1)$ \\
\hline Pleura & $122(3)$ & 0.2 & $6(5)$ \\
\hline Kidney/genito-urinary & $113(3)$ & 0.2 & $4(4)$ \\
\hline Bone/joint & $94(3)$ & 0.2 & $3(3)$ \\
\hline Gastro-intestinal & $43(1)$ & 0.1 & $3(7)$ \\
\hline Central nervous & & & \\
\hline system & $33(1)$ & 0.1 & $7(21)$ \\
\hline Other & $179(5)$ & 0.3 & $10(6)$ \\
\hline Not reported & $847(23)$ & 1.5 & $36(4)$ \\
\hline \multicolumn{4}{|l|}{ Case classification } \\
\hline New diagnosis & $2753(73)$ & 4.9 & $137(5)$ \\
\hline Reactivation & $200(5)$ & 0.4 & $11(6)$ \\
\hline Not reported & $801(21)$ & 1.4 & $36(4)$ \\
\hline Laboratory confirmed & 2607 (69) & 4.6 & $148(6)$ \\
\hline Total & 3754 & 6.6 & $184(5)$ \\
\hline
\end{tabular}

(two per cent) in Oceania (8.2/100,000), six (one per cent) in the Americas $(8.3 / 100,000)$, eight (two per cent) in the Middle East (7.1/100,000), and for 12 (three per cent) place of birth was not reported.

Rates were slightly higher in males compared with females, and higher among persons living in the Sydney area (covered by the Northern Sydney, Central Sydney, South Eastern Sydney, South Western Sydney, Western and Wentworth Area Health Services). The high incidence among persons living in Sydney is most likely due to more persons from high prevalence countries living in Sydney than in other parts of NSW (Table 6). In 1999, 417 (86 per cent) of 483 cases resided in the Sydney area.

\section{Disease}

For all cases 1991 to 1999 , the major reported site of disease was lung disease, followed by lymphatic disease and pleural disease. In 1999, the major site of disease was reported for 97 per cent. Of these, 69 per cent were reported to have lung disease, 14 per cent lymphatic disease, and three per cent pleural disease as the major site. For the period 1991 to 1999, where case classification was reported, 93 per cent were diagnosed with tuberculosis for the first time, and seven per cent had reactivated disease. In 1999, case classification was reported for 98 per cent, and of these, 95 per cent were reported to have been diagnosed with tuberculosis for the first time, while five per cent were reactivations. For all cases 1991 to 1999 , just over two-thirds of patients were reported to have been laboratory confirmed (Table 6). This proportion was stable in all years except 1991, when there may have been underreporting. In 1999, 70 per cent (339) were confirmed by laboratory reporting (Table 6 ).

\section{Sputum}

During the nine-year period, among the 1902 cases reported to have any pulmonary disease, sputum microscopy results were reported for 63 per cent (Table 7). In about half of these, acid-fast bacilli (AFBs) were identified on direct sputum smears. Among the 62 per cent of pulmonary cases where results were reported, for 71 per cent $M$. tuberculosis was cultured in the sputum. In 1999, sputum results were recorded for 88 per cent (287 of 328) pulmonary cases. Of these, half were AFB positive. In 1999 , among the 88 per cent ( 287 of 328) pulmonary cases where culture results were reported, for 76 per cent (219) M. tuberculosis was cultured. 


\section{HIV co-infection}

HIV infection was reported in 56 peoplewith tuberculosis (1.5 per cent) over the nine-year period. The year with the highest number of reported cases of HIV-tuberculosis coinfection was 1993, with 13 (3.3 per cent). In 1999, HIV infection was reported in eight people with tuberculosis (1.7 per cent).

\section{Hospitalisations}

Of the 3,754 tuberculosis cases notified from 1991 to 1999 , 1,683 (45 per cent) were reported to have been admitted to hospital. These data are likely to be incomplete, especially in the early part of the period. In 1999, 43 per cent of patients were reported to have been admitted to hospital.

\section{Deaths}

During the nine-year period, there were 184 deaths reported among patients with tuberculosis that were notified to public health units (five per cent of all cases). By year, reported deaths varied from two per cent in 1991 to seven per cent in 1993. Case fatality rates were higher among males, persons aged 65 years or older, persons born in Australia and Europe (who tend to be older), persons with central nervous system disease and persons living in rural areas (most likely because that is where older cases lived) (Table 6).

\section{DISCUSSION}

These data indicate that while NSW enjoys a relatively low incidence of tuberculosis by world standards, some groups are at increased risk of disease, including persons born in countries with a high prevalence of the disease, notably in Asia and Africa (who are more likely to live in the Sydney area), and older persons (who may have acquired infection in the past when tuberculosis was more common in the Australian community). HIV coinfection remains unusual in NSW with reported rates much lower than in many other developed countries. ${ }^{2}$

The increase of 83 cases reported in 1999 over 1998 (25 per cent) may be partially explained by delayed reporting of some cases in 1998 (the lowest case count in recent years), but is largely attributed to cases among persons immigrating from Asia (including East Timorese refugees) and Europe (including Kosovar refugees). Thanks to an elaborate case-finding system among refugees, further transmission from these cases is unlikely.

Timely notification of tuberculosis allows for the implementation of public health action to minimise

\section{TABLE 7}

CHARACTERISTICS OF PATIENTS NOTIFIED WITH PULMONARY TUBERCULOSIS, NSW, 1991-1999

\begin{tabular}{|lccc|}
\hline Pulmonary cases & $\begin{array}{c}\text { Cases } \\
\text { (\% total) }\end{array}$ & $\begin{array}{c}\text { Average } \\
\text { annual rate } \\
\text { per 100,000 }\end{array}$ & $\begin{array}{c}\text { Deaths } \\
\text { (\% of cases) }\end{array}$ \\
\hline Direct smear positive & & & \\
Yes & $601(32)$ & 1.1 & $39(6)$ \\
No & $590(31)$ & 1.0 & $27(5)$ \\
Not reported & $711(37)$ & 1.3 & $45(6)$ \\
Culture positive & & & \\
Yes & $846(44)$ & 1.5 & $52(6)$ \\
No & $345(18)$ & 0.6 & $14(4)$ \\
Not reported & $711(37)$ & 1.3 & $45(6)$ \\
\hline Total & 1902 & 3.4 & $111(6)$ \\
\hline
\end{tabular}

further transmission of the infection through the early identification, counselling, screening and treatment of exposed contacts. Notification also provides valuable data on trends and risk factors in persons with tuberculosis that allow the development of targeted prevention and control programs. The current surveillance system however does not collect data on several risk factors among patients, such as pre-existing medical conditions, nor does it consistently record useful information on drug resistance patterns among cases. These data are essential if we are to improve our understanding and therefore control of this disease, and NSW Tuberculosis Coordinators and Public Health Units are working closely with the NSW Department of Health's Communicable Diseases Surveillance and Control Unit to enhance the confidential reporting of this information.

\section{ACKNOWLEDGEMENT}

We acknowledge the role of the staff of Chest Clinics, Public Health Units and laboratories, and doctors in collecting and reporting data on NSW tuberculosis cases.

\section{REFERENCES}

1. Chin J (editor). Control of Communicable Diseases Manual. 17th edition. Washington, DC: American Public Health Association, 2000.

2. Centers for Disease Control and Prevention. Prevention and treatment of tuberculosis Among Patients Infected with Human Immunodeficiency Virus: Principles of Therapy and Revised Recommendations. Morb Mortal Wkly Rep 1998; 47 (RR20):1-51. 唪 